\title{
Bioaccumulation of total mercury in the earthworm Eisenia andrei
}

\author{
Shirley Le Roux ${ }^{1}$, Priscilla Baker ${ }^{1 *}$ and Andrew Crouch ${ }^{2}$
}

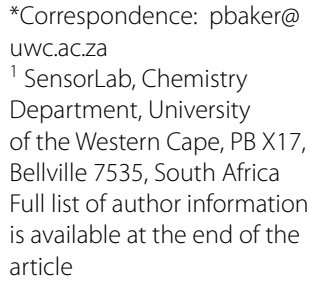

\begin{abstract}
Earthworms are a major part of the total biomass of soil fauna and play a vital role in soil maintenance. They process large amounts of plant and soil material and can accumulate many pollutants that may be present in the soil. Earthworms have been explored as bioaccumulators for many heavy metal species such as Pb, Cu and Zn but limited information is available for mercury uptake and bioaccumulation in earthworms and very few report on the factors that influence the kinetics of Hg uptake by earthworms. It is known however that the uptake of $\mathrm{Hg}$ is strongly influenced by the presence of organic matter, hence the influence of ligands are a major factor contributing to the kinetics of mercury uptake in biosystems. In this work we have focused on the uptake of mercury by earthworms (Eisenia andrei) in the presence of humic acid (HA) under varying physical conditions of $\mathrm{pH}$ and temperature, done to assess the role of humic acid in the bioaccumulation of mercury by earthworms from soils. The study was conducted over a 5-day uptake period and all earthworm samples were analysed by direct mercury analysis. Mercury distribution profiles as a function of time, bioaccumulation factors (BAFs), first order rate constants and body burden constants for mercury uptake under selected conditions of temperature, $\mathrm{pH}$ as well as via the dermal and gut route were evaluated in one comprehensive approach. The results showed that the uptake of $\mathrm{Hg}$ was influenced by $\mathrm{pH}$, temperature and the presence of $\mathrm{HA}$. Uptake of $\mathrm{Hg}^{2+}$ was improved at low $\mathrm{pH}$ and temperature when the earthworms in soil were in contact with a saturating aqueous phase. The total amount of $\mathrm{Hg}^{2+}$ uptake decreased from 75 to $48 \%$ as a function of $\mathrm{pH}$. For earthworms in dry soil, the uptake was strongly influenced by the presence of the ligand. Calculated BAF values ranged from 0.1 to 0.8 . Mercury uptake typically followed first order kinetics with rate constants determined as 0.2 to $1 \mathrm{~h}^{-1}$.
\end{abstract}

Keywords: Bioavailability, Bioaccumulation, Bioaccumulation factor, Humic acid, Earthworms, Soil, Mercury

\section{Background}

Organic matter strongly affects the binding of mercury ions in the environment and affects the mobility and bioavailability of this metal in sediments (Gismera et al. 2007). Mercury (and also other metals) can be reintroduced into the aquatic systems if the solubility, mobility and bioavailability changes as a result of a change in different environmental factors such as $\mathrm{pH}$, salt concentration, the presence of complexing agents, and temperature. Sediments can be a long-term source of $\mathrm{Hg}$ to surface waters. Sediments are an important location as storage reservoirs for elemental mercury and facilitate $\mathrm{Hg}$

(c) 2016 The Author(s). This article is distributed under the terms of the Creative Commons Attribution 4.0 International License (http://creativecommons.org/licenses/by/4.0/), which permits unrestricted use, distribution, and reproduction in any medium, provided you give appropriate credit to the original author(s) and the source, provide a link to the Creative Commons license, and indicate if changes were made. 
methylation, resulting in high concentrations of the more toxic monomethylmercury $\left(\mathrm{CH}_{3} \mathrm{Hg}^{+}\right)$in organisms (Inza et al. 1997; Lawrence and Mason 2001; Burton et al. 2006; Windmöller et al. 2015).

The toxicity of $\mathrm{Hg}$ to terrestrial invertebrates and its effects on survival, reproduction and growth is not well documented although such information is important for risk assessment from $\mathrm{Hg}$ pollution in terrestrial ecosystems. The toxicity of $\mathrm{Hg}^{2+}$ is strongly linked to its affinity for the sulphydryl groups, which are found in most proteins (Gudbrandsen et al. 2007). Earthworms in particular, have the ability to bioaccumulate toxins and can concentrate them internally to high levels. In turn they form the basis of many food chains, thereby passing these high levels on to the wildlife that feed on them. This poses a serious risk of secondary poisoning of these predators due to bio-magnification (Kamitani and Kaneko 2007). Because of the intricate relationship between earthworms and the soil and its contaminants, they can serve as useful biological indicators of soil contamination (Veiga et al. 1999; Dai et al. 2004).

Earthworms eat their way through soil, digest it and deposit it as waste, thereby aerating and mixing the soil (Ernst et al. 2008). This process enhances the uptake of nutrients in the soil by plants. Earthworms can survive high-level of exposure by regularly crawling out of the exposure mixture. This practice decreases their contact time with the contaminated soil (Gudbrandsen et al. 2007). Bioaccumulation of $\mathrm{Cu}, \mathrm{Cd}, \mathrm{Pb}$ and $\mathrm{Zn}$ by earthworms is well documented and is thought to be in the chloragogenous tissue surrounding the posterior alimentary canal (Li et al. 2010). There are two pathways for the intracellular binding of metals in the chloragogenous tissue. The one pathway binds metals to insoluble, O-donating, phosphate-rich granules (chloragosomes) while the other pathway binds metals to low molecular, S-donating ligands (Sizmur and Hodson 2009). Uptake of $\mathrm{Hg}$ by earthworms could be by dermal route or uptake by the gut; the dermal route was however found to be more important, with more than $96 \%$ of $\mathrm{Hg}$ found to be taken up by the dermal route (Hobbelen et al. 2006). Contamination in pore water is more available to earthworms for dermal uptake and thus uptake of metals is considered to be mainly via the dermal route. A different fraction of the heavy metal contaminants was present in the gut due to dietary intake because ingested materials are buffered to near neutral pH (Kamitani and Kaneko 2007). These studies typically report on the accumulation of heavy metals from contaminated soil but very few have measured uptake from water (Ernst et al. 2008; Sizmur and Hodson 2009; Calisi et al. 2013; Windmöller et al. 2015). As dermal uptake is very important, determining the accumulation of the metal fraction by water could provide strong evidence of metal mobility and availability (Sizmur and Hodson 2009). The bioavailability of pollutants in soil can be influenced by factors such as $\mathrm{pH}$, cation exchange capacity as well as organic content. In previous reports where earthworms were placed in contaminant $\mathrm{Cu}$ bearing solutions, the focus was on differentiating between uptake via pore water and the dermal route (Arnold et al.2003; Steenbergen et al. 2005).

In the present study uptake of $\mathrm{Hg}$ by earthworms was quantitatively evaluated by placing earthworms in an aqueous/soil controlled microcosm as well as in a dry soil microcosm to assess uptake and bioaccumulation via the important dermal route as well as the gut route. The impact of dissolved $\mathrm{HA}$ on the bioavailability of $\mathrm{Hg}^{2+}$ was investigated 
under varying physical conditions of temperature and $\mathrm{pH}$ in controlled laboratory experiments.

\section{Experimental}

\section{Test organism, study soil, aqueous phase and sample preparation}

The experiment microcosm ( $2 \mathrm{~L}$ beaker) containing the aqueous phase, soil and earthworms were placed in a temperature controlled room and the experimental microcosms were exposed to a photo-period of $16 \mathrm{~h}$ of light (Fig. 1). The experimental set-up containing the aqueous phase required that air be bubbled through, for the preservation of the earthworms. The microcosms were also continually aerated after addition of the earthworms. The earthworms were not fed and the water was not changed in the microcosms over the 5 day duration of the experiments to avoid any factors associated with changes in soil geochemistry. Triplicate samples of all experiments were prepared and analysed separately by direct mercury analyser (DMA).

The aqueous phase (Fig. 1a) was prepared by taking a saline solution, prepared from distilled water and $\mathrm{NaCl}$ to a final concentration of $35 \mu \mathrm{g} / \mathrm{mL}$, spiking it with $\mathrm{Hg}^{2+}$ to $5 \mu \mathrm{g} / \mathrm{mL}$. The $\mathrm{pH}$ of this solution was adjusted using acetic acid/ammonium buffer, 5.5, 7 and 8 respectively, in separate experiments as reported in Tables 2, 3 and 4. Soil pH, per se, was not measured as an experimental variable. After the aqueous phase was prepared, it was added on top of the soil layer and allowed to filter through and equilibrate, before the earthworms were introduced to the system.

Earthworms Eisenia andrei was the biota selected for the study of the uptake of $\mathrm{Hg}^{2+}$ in the presence of HA under different physical conditions. The earthworms were at least 6 weeks old adults of uniform size with well-developed clitella. They were allowed to depurate (the earthworms were left on damp filter paper in petri dishes without food to empty their guts) for 1 day before adding them to the experimental microcosms (30 earthworms/microcosm). During the experiment the earthworms were not fed, and in this way absorption via dermal and gut route was controlled to reflect only what was introduced to the microcosm for experimental purposes (Fig. 1b). After sampling the earthworms were not depurated as the experiment was designed to look at the distribution across all phases and gut content was part of the experimental data.

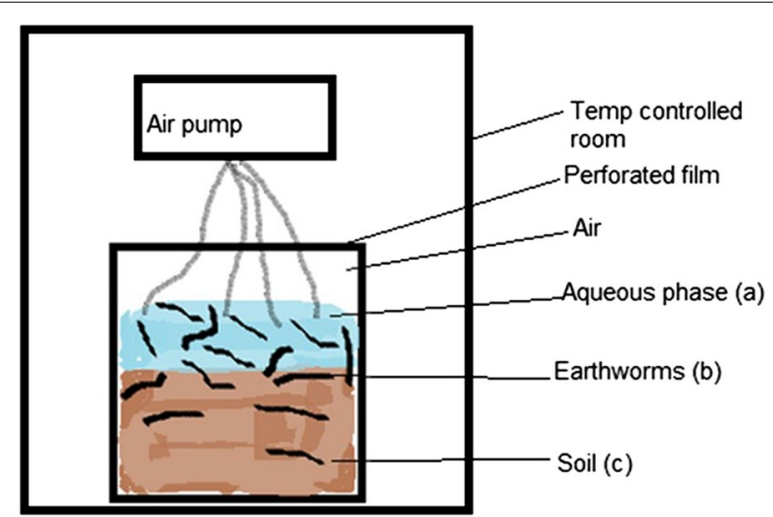

Fig. 1 Schematic diagram of the experiment to determine the uptake of $\mathrm{Hg}$ by earthworms in the presence of $\mathrm{HA}$ 
The soil layer (Fig. 1c) for each experiment was prepared by placing 6-cm layer (600 g) of previously cleaned soil in $2 \mathrm{~L}$ beakers. The HA solution, prepared from a soluble form of HA (Sigma Aldrich Catalogue number H1, 675-2 Lot::S33786-057) was added to a final calculated concentration of $5 \mu \mathrm{g} / \mathrm{g} \mathrm{HA}$ in the microcosm and left for $12 \mathrm{~h}$ to equilibrate at $4{ }^{\circ} \mathrm{C}$, after which the aqueous phase and earthworms were added (wet microcosm). A control sample was prepared in the same way but without the addition of HA solution.

The sampling period of 5 days was based on a literature precedent from a similar investigation. Laboratory experiments carried out with amphipods, (Lawrence and Mason 2001) showed that a 6-day time period did not significantly affect invertebrate survival ( $>90 \%$ average survival). The assumption was that treatment used in this study would not affect the percentage survival and growth of earthworms.

In a separate experiment (dry microcosm) 6-cm layer (600 g) of previously cleaned soil was placed in $2 \mathrm{~L}$ beakers (Fig. 2a). The soil was spiked with $0.5 \mu \mathrm{g} / \mathrm{g} \mathrm{Hg}^{2+}$ as before and the same concentration HA was used in the $12 \mathrm{~h}$ equilibration at $4{ }^{\circ} \mathrm{C}$, before the earthworms were added (Fig. 2b). The control sample for the dry microcosm was prepared in the same way but without adding the HA. Triplicate samples of all experiments was prepared and analysed separately by direct mercury analyser (DMA).

\section{Analytical procedures for determining the bioaccumulation $\mathrm{Hg}^{2+}$ in earthworms}

The respective volume of water, soil and earthworm were collected and immediately frozen. All earthworm samples consisted of three earthworms randomly collected at each time interval. Triplicate samples of all phases (aqueous, soil and earthworms) were taken and analysed separately. The sampling period was 5 days; but most samples were taken and analysed within the first 2 days. First experiments in aqueous phase only which were recorded over a nine-day period indicated that most of the complexation took place within the first $48 \mathrm{~h}$. Samples were stored in acid-cleaned Teflon storage containers and refrigerated until subsequent analysis. Analysis was performed using DMA for all samples, to obtain total $\mathrm{Hg}$ concentrations and to determine losses of $\mathrm{Hg}^{2+}$ from the experimental system.

The frozen samples were transferred to the analytical laboratory and analysed with DMA by the CSIR (Council for Scientific and Industrial Research; Natural Resources and Environment) as a paid service. It is the standard method employed by the CSIR for total mercury analysis. No pre-treatment of the sample was required and the method was suitable for solid and liquid samples. Because no digestion of the sample was needed

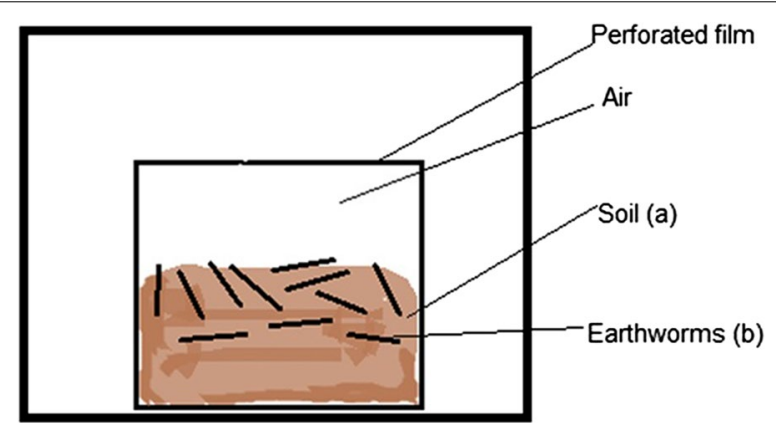

Fig. 2 Schematic diagram of the experiment to determine the uptake of $\mathrm{Hg}$ by earthworms in the presence of $\mathrm{HA}$ 
there was no need for corrosive chemicals and the production of hazardous waste was minimal. The method also has a very good detection limit (Ipolyi et al. 2004). A dual cell atomic absorption spectrometer (AA) was used to determine elemental $\mathrm{Hg}$ absorption at a wavelength of $253.65 \mathrm{~nm}$. Triplicate measurements were run on all of the samples, and standard reference materials were run between every 8 samples. A 0.2-0.5 g sample was placed into the sample boat, the sample was weighed, dried for a set period and then thermally decomposed. This process heated the sample to release the mercury and the vapours were carried by oxygen flow to an amalgamator for selective trapping of mercury on a gold trap. After a short heating period, the mercury released was measurement by atomic absorption (Ipolyi et al. 2004; Kading et al. 2009). The certified reference material used was Tort- 2 and the $\mathrm{Hg}$ concentration found $(237.37 \pm 31.19)$ was in good agreement with the certified value at a $95 \%$ confidence level.

\section{Results and discussion}

\section{Determination of the complexation of $\mathrm{Hg}^{2+}$ with $\mathrm{HA}$ in aqueous phase, soil and earthworms at a fixed temperature of $293.15 \mathrm{~K}$ and variable $\mathrm{pH}$}

The complexation of $\mathrm{Hg}$ by earthworms in the absence of $\mathrm{HA}$ was done, at $\mathrm{pH} 5.5$ only. For this control experiment, the $\mathrm{Hg}^{2+}$ concentration in aqueous phase was observed to decrease at the same time as the concentration of $\mathrm{Hg}^{2+}$ in the soil and the earthworms increased.

From the time based studies over a period of $48 \mathrm{~h}$, the uptake of mercury followed a time dependent profile during the first $0-5 \mathrm{~h}$. The distribution of mercury between soil, earthworms and aqueous phase in the control experiment, was clearly established by the trends observed from DMA analysis of the appropriate samples for mercury content (Fig. 3).

The concentration of $\mathrm{Hg}^{2+}$ in the earthworms increased to a maximum of $74.1 \%$, within the first $1 \mathrm{~h}$, after which a steady state was reached (Table 1). From the total amount of mercury available in the aqueous phase $(5 \mu \mathrm{g} / \mathrm{g})$, the maximum concentration of $\mathrm{Hg}^{2+}$ absorbed by earthworms was at $4 \mathrm{~h}(3.64 \mu \mathrm{g} / \mathrm{g})$. The maximum adsorption measured for soil was $0.58 \mu \mathrm{g} / \mathrm{g}$ and the remaining $\mathrm{Hg}^{2+}$ in the aqueous was $0.12 \mu \mathrm{g} / \mathrm{g}$. Hence, applying mass balance principles to the concentration distribution in earthworms at time $=1 \mathrm{~h}(79.2 \%)$ and at time $=4 \mathrm{~h}(86.8 \%)$ we can account for the total distribution of $\mathrm{Hg}^{2+}$ in the system $\left(\mathrm{Hg}_{\text {aqueous phase }}+\mathrm{Hg}_{\text {soil }}+\mathrm{Hg}_{\text {earthworms }}\right)$ (dotted line).

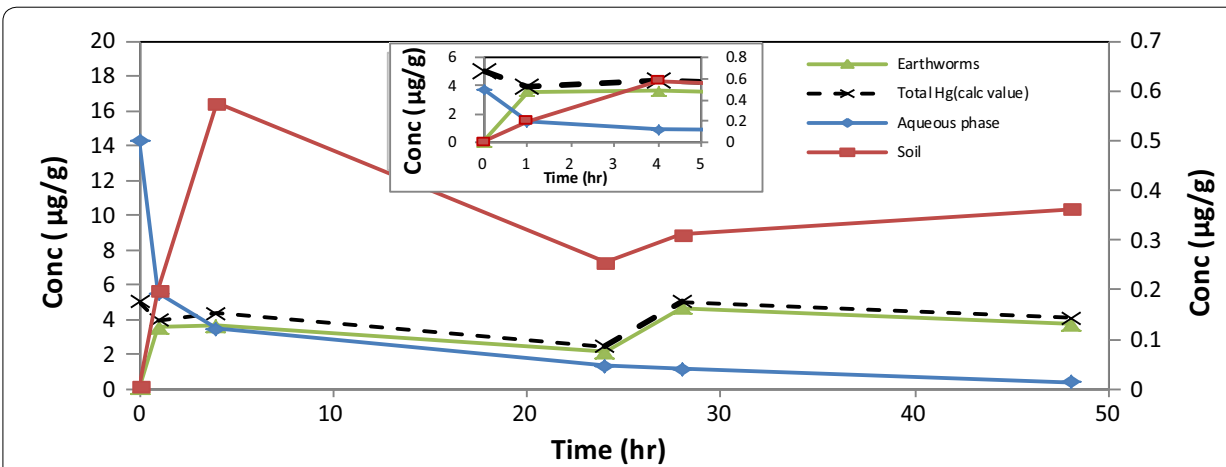

Fig. 3 Distribution of $\mathrm{Hg}^{2+}$ in aqueous phase, soil and earthworms at pH 5.5 at $293.15 \mathrm{~K}$ without any HA present. Earthworm and total $\mathrm{Hg}$ values are displayed on primary axis while the aqueous phase and soil values are on the secondary axis 
Table 1 DMA measurements of $\mathbf{H g}^{2+}$ uptake control experiment for soil, earthworms and remaining in aqueous phase

\begin{tabular}{lclcl}
\hline pH values & Time (h) & $\begin{array}{l}\text { Concentration (\%) } \\
\text { remaining in aqueous } \\
\text { phase }\end{array}$ & $\begin{array}{l}\text { Concentration (\%) } \\
\text { in soil }\end{array}$ & $\begin{array}{l}\text { Concentration (\%) } \\
\text { in earthworms }\end{array}$ \\
\hline pH 5.5 & 1 & 3.9 & 4.0 & 71.4 \\
pH 5.5 & 4 & 2.4 & 11.6 & 72.8 \\
pH 5.5 & 24 & 0.9 & 5.1 & 43.1 \\
\hline
\end{tabular}

The complexation experiments were then repeated in the presence of $\mathrm{HA}$, at three different $\mathrm{pH}$ values $(5.5,7.0$ and 8.0$)$ to observe the effect of $\mathrm{pH}$ on mercury uptake.

Following the same data analysis approach as for control experiment, the distribution of mercury between soil, earthworms and aqueous phase in the presence of HA, could account for $94.1 \%$ (after $1 \mathrm{~h}$ ) and $99.4 \%$ (after $4 \mathrm{~h}$ ) of the total $\mathrm{Hg}$ injected into the biosystem, initially (Fig. 4). Hence, we can account for the total distribution of $\mathrm{Hg}^{2+}$ in the system using the mass balance approach, based on measurements of $\mathrm{Hg}$ done by DMA (dotted line). The high correlation for mercury distribution is directly attributed to the complexation effect of the HA at pH 5.5 (Fig. 5).

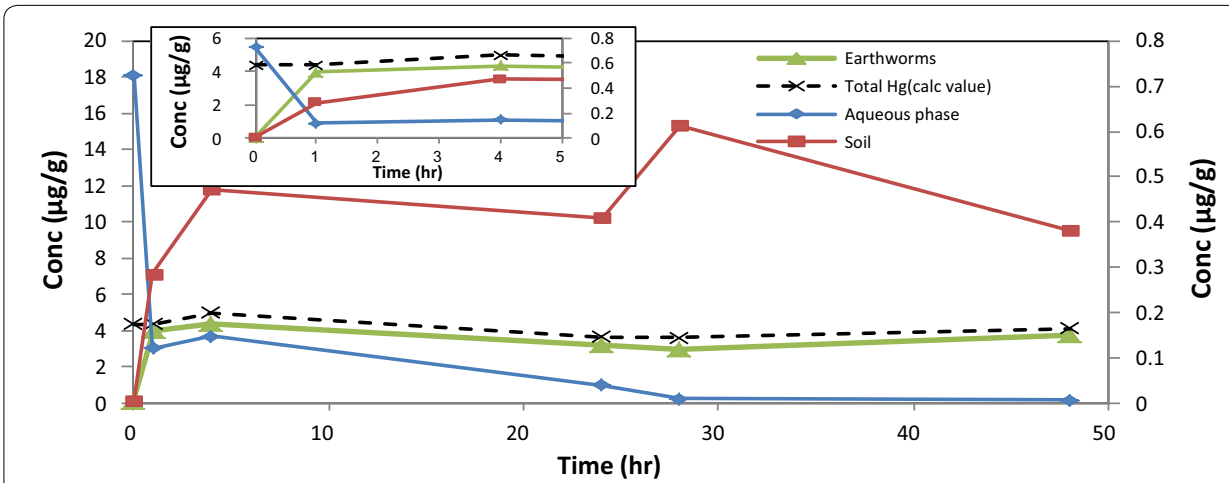

Fig. 4 Distribution of $\mathrm{Hg}^{2+}$ in aqueous phase, soil and earthworms in the presence of $\mathrm{HA}$ at $\mathrm{pH} 5.5$ at 293.15 K. Earthworm and total $\mathrm{Hg}(\mathrm{calc})$ values are displayed on primary axis while the aqueous phase and soil values are on the secondary axis

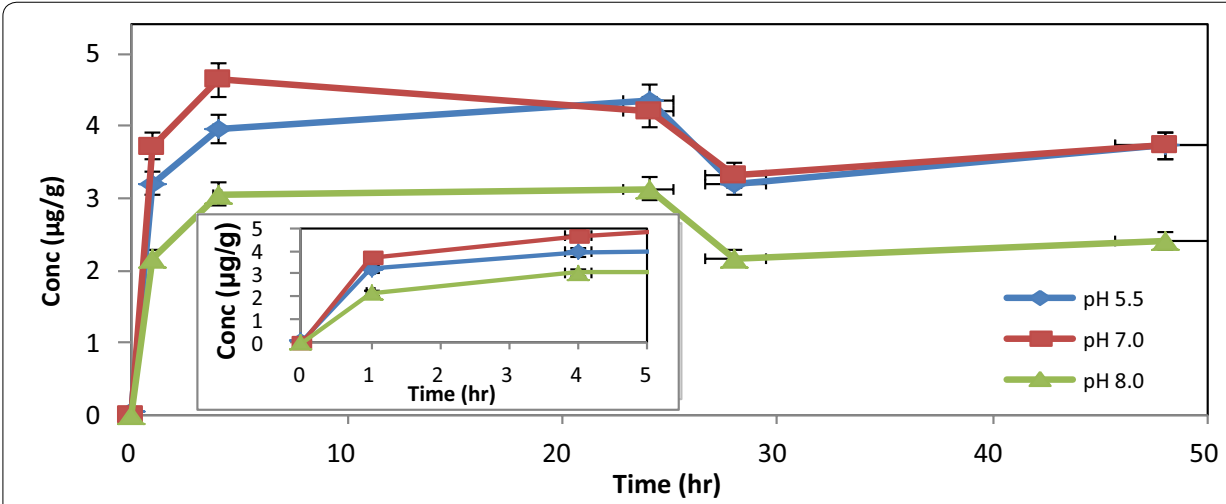

Fig. 5 Distribution of $\mathrm{Hg}^{2+}$ in earthworms in aqueous phase, at different $\mathrm{pH}$ values at $293.15 \mathrm{~K}$ (error bars represent $\mathrm{SE}, \mathrm{n}=3$ ) 
Similar distribution profiles for $\mathrm{Hg}$ in the presence of $\mathrm{HA}$ were obtained at $\mathrm{pH} 7.0$ and 8.0. The proportion of $\mathrm{Hg}^{2+}$ in the different samples, at these $\mathrm{pH}$ values were tabulated as the mass balance distribution (Table 2).

Accumulation of $\mathrm{Hg}^{2+}$ in earthworms was less effective at $\mathrm{pH}$ 8.0. $\mathrm{pH}$ has been identified from literature as being one of the most important parameters that determines uptake of $\mathrm{Hg}$ by earthworms (Burton et al. 2006; Ernst et al. 2008). At the beginning of these experiments absorption of $\mathrm{Hg}$ was attributed to absorption via the dermal route, due to the skin contact provided by the aqueous phase. However the fluctuation observed in absorption profiles over the extended time period, could be attributed to mixed absorption via dermal as well as the gut route, which are influenced by different physical parameters.

\section{Determination of the complexation of $\mathrm{Hg}^{2+}$ with $\mathrm{HA}$ in soil and uptake by earthworms at different temperatures and ambient $\mathrm{pH}$}

In subsequent experiments the uptake of mercury by earthworms in dry soil, in the absence of the aqueous phase, was studied at $298.15 \mathrm{~K}$ and $303.15 \mathrm{~K}$. The experimental set-up was the same but the aqueous phase was excluded. The $\mathrm{Hg}^{2+}$ concentration in the soil decreased while the concentration of $\mathrm{Hg}$ in the earthworms increased rapidly. The data showed an equilibrium condition between 4 and $24 \mathrm{~h}$ in the soil, a rapid increase between 24 and $28 \mathrm{~h}$, and then a steady state condition (Figs. 6, 7). The accumulation of $\mathrm{Hg}^{2+}$ concentration in the earthworms after $48 \mathrm{~h}$ was best observed at $298.15 \mathrm{~K}$, since the higher temperature resulted in expiration of the earthworms.

The distribution of mercury during $0-5 \mathrm{~h}$ between soil and earthworms were clearly established. From the total amount of mercury available in the soil $(0.5 \mu \mathrm{g} / \mathrm{g})$, the maximum concentration of $\mathrm{Hg}^{2+}$ absorbed by earthworms at $298.15 \mathrm{~K}$ after $48 \mathrm{~h}$ was $(0.42 \mu \mathrm{g} / \mathrm{g})$ and $(0.16 \mu \mathrm{g} / \mathrm{g})$ at $303.15 \mathrm{~K}$. Accumulation of $\mathrm{Hg}^{2+}$ was thus higher at $298.15 \mathrm{~K}$. Hence, applying mass balance principles to the concentration distribution in earthworms at 293.15 and $303.15 \mathrm{~K}$ at time $=1 \mathrm{~h}$ was $(4.4 \%)$ and $(7.8 \%)$ respectively and at time $=4 \mathrm{~h}(14.2 \%)$ and $(12.6 \%)$ we can account for the total distribution of $\mathrm{Hg}^{2+}$ in the system $\left(\mathrm{Hg}_{\text {soil }}+\mathrm{Hg}_{\text {earthworms }}\right)$ (dotted line). The overall percentages for mercury distribution was again higher when the HA was added.

Table 2 Distribution profile of $\mathrm{Hg}^{2+}$ in presence of $\mathrm{HA}$ in soil, earthworms and remaining in aqueous phase

\begin{tabular}{lclll}
\hline pH values & Time (h) & $\begin{array}{l}\text { Concentration (\%) } \\
\text { remaining in aqueous phase }\end{array}$ & $\begin{array}{l}\text { Concentration (\%) } \\
\text { in soil }\end{array}$ & $\begin{array}{l}\text { Concentration (\%) } \\
\text { in earthworms }\end{array}$ \\
\hline pH 5.5 & 1 & 14.2 & 5.7 & 74.2 \\
pH 5.5 & 4 & 10.9 & 9.5 & 79.0 \\
pH 5.5 & 24 & 0.8 & 8.2 & 87.0 \\
pH 7.0 & 1 & 3.5 & 4.8 & 74.3 \\
pH 7.0 & 4 & 1.9 & 4.3 & 92.3 \\
pH 7.0 & 24 & 0.64 & 5.4 & 84.0 \\
pH 8.0 & 1 & 2.7 & 9.5 & 43.4 \\
pH 8.0 & 4 & 1.1 & 12.0 & 78.1 \\
pH 8.0 & 24 & 0.5 & 13.2 & 62.5 \\
\hline
\end{tabular}



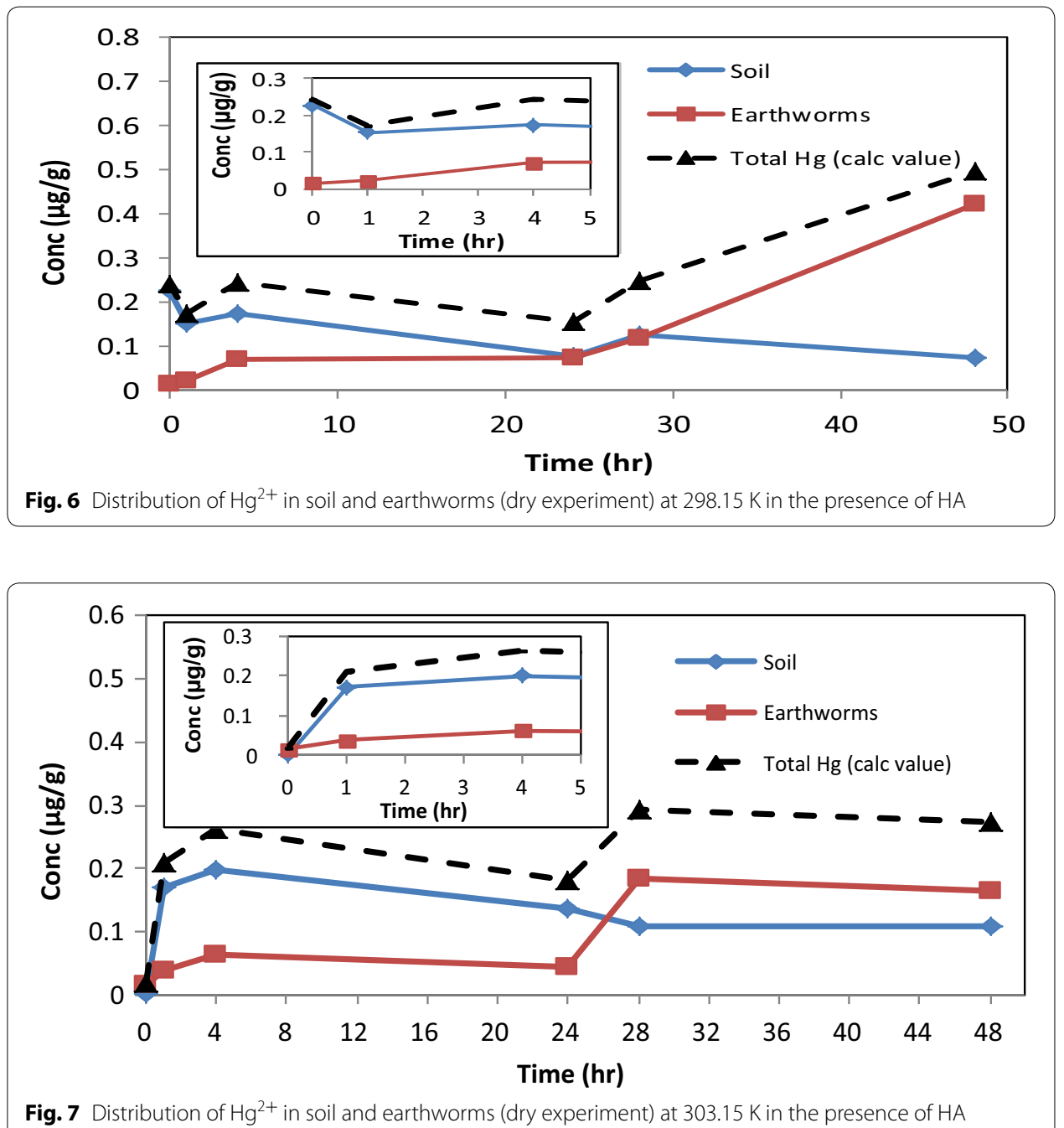

Accumulation of $\mathrm{Hg}$ in earthworms was faster and at higher concentration levels in the aqueous phase. The faster rates represent uptake of $\mathrm{Hg}^{2+}$ mainly via the dermal route. $\mathrm{Hg}$ distribution profiles based on mass balance of concentrations determined by DMA, account fully for the original value of $\mathrm{Hg}^{2+}$ introduced to the bio-system. The best distribution profile $(99.4 \%$ accountable) was obtained for aqueous phase experiment at $\mathrm{pH} 5.5$ in the presence of HA. The best distribution profile for soil experiments (i.e. no aqueous phase) was found at lower temperature (84\%). In the soil experiments the absorption takes place mainly via the gut route.

\section{Kinetics for the complexation of $\mathrm{Hg}^{2+}$ with $\mathrm{HA}$ in earthworms}

$\mathrm{Hg}$ accumulation trends in earthworms, in the absence of HA (control study) was compared to the expected trend from literature (Veiga et al. 1999; Windmöller et al. 2015). The expected trend is an increase in Hg levels until a maximum after which the concentration remains constant, after which the earthworms expire (Gudbrandsen et al. 2007) (Fig. 8). 


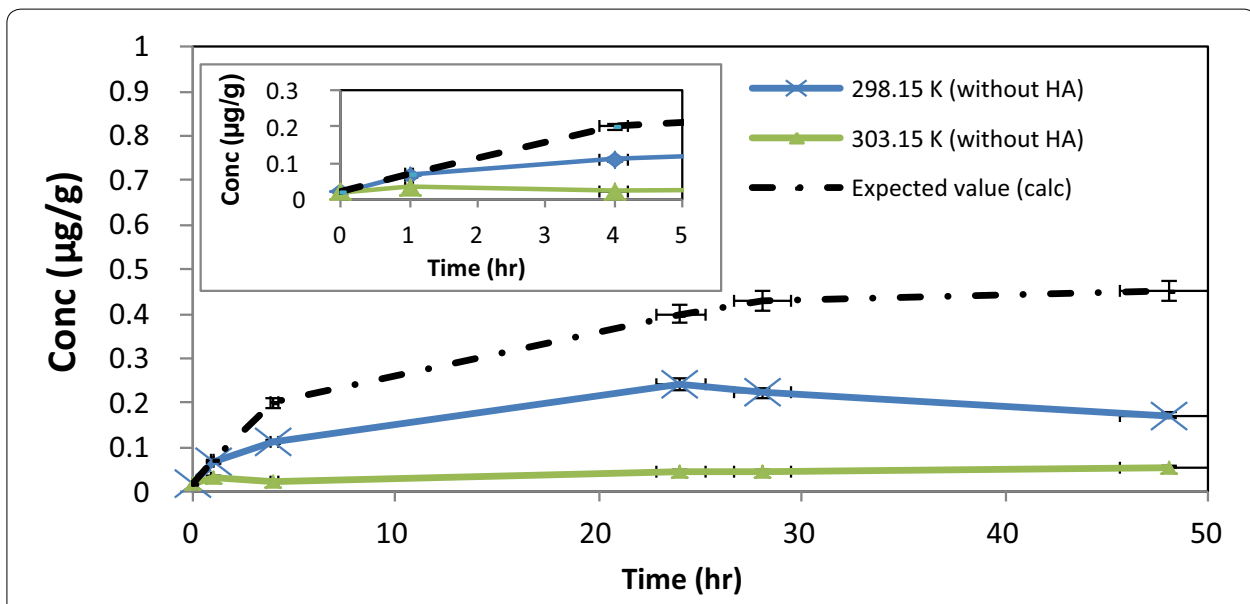

Fig. 8 Accumulation of $\mathrm{Hg}^{2+}$ in earthworms at 298.15 and $303.15 \mathrm{~K}$ without any $\mathrm{HA}$ present, in soil experiments (error bars represent $\mathrm{SE}, \mathrm{n}=3$ )

The control study confirmed that accumulation of $\mathrm{Hg}^{2+}$ in earthworms was favoured by lower temperature and represented uptake of $\mathrm{Hg}^{2+}$ mainly via the gut route. $\mathrm{Hg}$ absorption experiments, in the presence of HA, showed similar trends at 298.15 and $303.15 \mathrm{~K}$, for accumulation of $\mathrm{Hg}^{2+}$ in earthworms up to $30 \mathrm{~h}$ after which the lower temperature evaluated, again showed a higher uptake of $\mathrm{Hg}$ via the gut route in presence of HA (up to 5 days) (Fig. 9).

In the summary Table 3 the absorption of $\mathrm{Hg}$ by earthworms in the aqueous phase experiment (at time $48 \mathrm{~h}$ ) was highest at $293.15 \mathrm{~K}$ at pH 5.5 (lower $\mathrm{pH}$ and temperature). For the dry soil experiments $\mathrm{Hg}$ absorption was improved at the lower temperature and in the presence of HA (Table 3).

The total percentage of $\mathrm{Hg}$ remaining in all phases was calculated and divided by the total value of $\mathrm{Hg}$ spiked (distribution profile) in an attempt to account for any loss of $\mathrm{Hg}$ due to absorption onto container walls or abiotic reduction, i.e. not related to absorption by earthworms and complexation by HA. In this way we have demonstrated that the

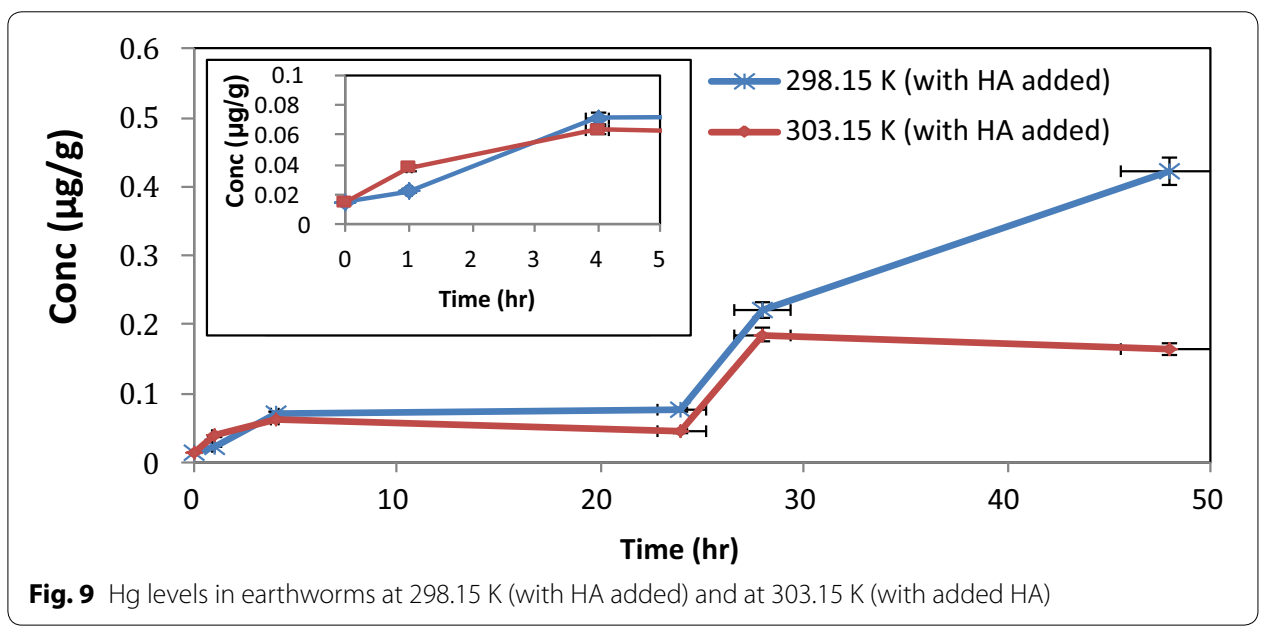


Table 3 Summary of $\mathrm{Hg}^{2+}$ uptake by earthworms as a function of temperature and $\mathrm{pH}$, at time $48 \mathrm{~h}$

\begin{tabular}{|c|c|c|c|c|c|c|c|}
\hline \multirow{2}{*}{\multicolumn{4}{|c|}{$\begin{array}{l}\text { Aqueous phase present } \\
293.15 \mathrm{~K}\end{array}$}} & \multicolumn{4}{|c|}{ Aqueous phase absent (dry soil experiment) } \\
\hline & & & & $298.15 \mathrm{~K}$ & & $303.15 \mathrm{~K}$ & \\
\hline $\begin{array}{l}\text { Control } \\
\text { (without HA) }\end{array}$ & $\begin{array}{l}\text { pH } 5.5 \\
\text { (with HA) }\end{array}$ & $\begin{array}{l}\mathrm{pH} 7.0 \\
\text { (with HA) }\end{array}$ & $\begin{array}{l}\mathrm{pH} 8.0 \\
\text { (with HA) }\end{array}$ & $\begin{array}{l}\text { Control } \\
\text { (without HA) }\end{array}$ & $\begin{array}{l}\text { Sample } \\
\text { (with HA) }\end{array}$ & $\begin{array}{l}\text { Control } \\
\text { (without HA) }\end{array}$ & $\begin{array}{l}\text { Sample } \\
\text { (with HA) }\end{array}$ \\
\hline $75 \%$ & $75 \%$ & $75 \%$ & $48 \%$ & $34 \%$ & $84 \%$ & $11 \%$ & $33 \%$ \\
\hline
\end{tabular}

distribution of $\mathrm{Hg}$ in a controlled environment can be fully accounted for. Highest losses were reported at high $\mathrm{pH}$, high temperature and in the absence of HA (Table 4).

\section{Bioaccumulation factor of $\mathrm{Hg}$ in earthworms}

Bioaccumulation factors (BAFs) can be used to estimate the bioavailability of metals to earthworm species (Nannoni et al. 2011). The U.S. Environmental Agency (2010) defined the Bioaccumulation factor as 'The ration of the contaminant in an organism to the concentration in the ambient environment at a steady state, where the organism can take in the contaminant through ingestion with its food as well as through direct content'. It is calculated as the ratio of the $\mathrm{Hg}$ concentration in the earthworm (in $\mu \mathrm{g} / \mathrm{g}$ dry wt) to the total soil Hg content (in $\mu \mathrm{g} / \mathrm{g}$ dry wt) (Álvarez et al. 2004; Rodríquez Álvarez et al. 2014; Nannoni et al. 2011). Previous studies (Burton et al. 2006; Nannoni et al. 2011) found $\mathrm{BAF}$ to be $<1$ which is in agreement with value obtained in the present study (Table 5).

Rate constants for the complexation of $\mathrm{Hg}^{2+}$ with $\mathrm{HA}$ in earthworms, for first order reaction Rate constants (k) (bioaccumulation rates) were calculated with first-order kinetic model (Gấrdfeldt 2003; Nannoni et al. 2011). A graph of ln conc vs time (h) was constructed and $k$ evaluated from the slope. A good fit was obtained with $r^{2}>0.99$ (Fig. 10).

Values obtained in this study ranged from 0.2 to $1 \mathrm{~h}^{-1}$. The highest values obtained were for rate constants calculated from low temperature and $\mathrm{pH}$ data for complexation of $\mathrm{Hg}^{2+}$ with HA present (Table 6).

Table $4 \mathrm{Hg}^{2+}$ percentage distribution profile, based on DMA analysis, at time $48 \mathrm{~h}$

\begin{tabular}{|c|c|c|c|c|c|c|c|}
\hline \multirow{2}{*}{\multicolumn{4}{|c|}{$\begin{array}{l}\text { Aqueous phase present } \\
293.15 \mathrm{~K}\end{array}$}} & \multicolumn{4}{|c|}{ Aqueous phase absent (dry soil experiment) } \\
\hline & & & & $298.15 \mathrm{~K}$ & & $303.15 \mathrm{~K}$ & \\
\hline $\begin{array}{l}\text { Control } \\
\text { (without HA) }\end{array}$ & $\begin{array}{l}\mathrm{pH} 5.5 \\
\text { (with HA) }\end{array}$ & $\begin{array}{l}\mathrm{pH} 7.0 \\
\text { (with HA) }\end{array}$ & $\begin{array}{l}\mathrm{pH} 8.0 \\
\text { (with HA) }\end{array}$ & $\begin{array}{l}\text { Control } \\
\quad \text { (without HA) }\end{array}$ & $\begin{array}{l}\text { Sample } \\
\text { (with HA) }\end{array}$ & $\begin{array}{l}\text { Control } \\
\text { (without HA) }\end{array}$ & $\begin{array}{l}\text { Sample } \\
\text { (with HA) }\end{array}$ \\
\hline $82 \%$ & $82 \%$ & $80 \%$ & $62 \%$ & $55 \%$ & $99 \%$ & $36 \%$ & $55 \%$ \\
\hline
\end{tabular}

Table 5 Bioaccumulation factor of $\mathrm{Hg}$ by earthworms at different temperature and $\mathrm{pHs}$ after $48 \mathrm{~h}$

\begin{tabular}{|c|c|c|c|c|c|c|c|}
\hline \multirow{2}{*}{\multicolumn{4}{|c|}{$\begin{array}{l}\text { Aqueous phase present } \\
293.15 \mathrm{~K}\end{array}$}} & \multicolumn{4}{|c|}{ Aqueous phase absent (dry soil experiment) } \\
\hline & & & & \multicolumn{2}{|l|}{$298.15 \mathrm{~K}$} & \multicolumn{2}{|l|}{$303.15 \mathrm{~K}$} \\
\hline $\begin{array}{l}\text { Control } \\
\text { (without HA) }\end{array}$ & $\begin{array}{l}\text { pH } 5.5 \\
\text { (with HA) }\end{array}$ & $\begin{array}{l}\mathrm{pH} 7.0 \\
\text { (with HA) }\end{array}$ & $\begin{array}{l}\mathrm{pH} 8.0 \\
\text { (with HA) }\end{array}$ & $\begin{array}{l}\text { Control } \\
\text { (without HA) }\end{array}$ & $\begin{array}{l}\text { Sample } \\
\text { (with HA) }\end{array}$ & $\begin{array}{l}\text { Control } \\
\text { (without HA) }\end{array}$ & $\begin{array}{l}\text { Sample } \\
\text { (with HA) }\end{array}$ \\
\hline 0.75 & 0.75 & 0.75 & 0.48 & 0.34 & 0.84 & 0.11 & 0.33 \\
\hline
\end{tabular}




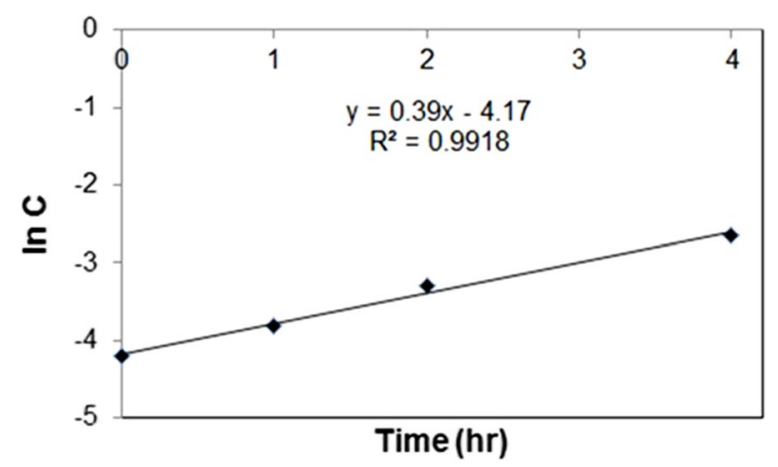

Fig. 10 Rate constant of the bioaccumulation of $\mathrm{Hg}$ by earthworms with HA present at $298.15 \mathrm{~K}$

Table 6 Summary table of rate constant $\left(\mathrm{hr}^{-1}\right)$ calculated for all complexation of $\mathrm{Hg}$ with HA

\begin{tabular}{|c|c|c|c|c|c|c|c|}
\hline \multirow{2}{*}{\multicolumn{4}{|c|}{$\begin{array}{l}\text { Aqueous phase present } \\
293.15 \mathrm{~K}\end{array}$}} & \multicolumn{4}{|c|}{ Aqueous phase absent (dry soil experiment) } \\
\hline & & & & \multicolumn{2}{|l|}{$298.15 \mathrm{~K}$} & \multicolumn{2}{|l|}{$303.15 \mathrm{~K}$} \\
\hline $\begin{array}{l}\text { Control } \\
\text { (without HA) }\end{array}$ & $\begin{array}{l}\mathrm{pH} 5.5 \\
\text { (with HA) }\end{array}$ & $\begin{array}{l}\mathrm{pH} 7.0 \\
\text { (with HA) }\end{array}$ & $\begin{array}{l}\mathrm{pH} 8.0 \\
\quad \text { (with HA) }\end{array}$ & $\begin{array}{l}\text { Control } \\
\text { (without HA) }\end{array}$ & $\begin{array}{l}\text { Sample } \\
\text { (with HA) }\end{array}$ & $\begin{array}{l}\text { Control } \\
\text { (without HA) }\end{array}$ & $\begin{array}{l}\text { Sample } \\
\text { (with HA) }\end{array}$ \\
\hline $0.4 \mathrm{~h}^{-1}$ & $0.9 h^{-1}$ & $1 h^{-1}$ & $1 h^{-1}$ & $0.4 \mathrm{~h}^{-1}$ & $0.4 h^{-1}$ & $0.2 h^{-1}$ & $0.3 h^{-1}$ \\
\hline
\end{tabular}

\section{Body burden calculations in earthworm}

The soil metal content has a huge impact on earthworm body burden. Regression models have been used to calculate the body burden of earthworms from contaminated soils. Body burden calculations relate metal concentrations to soil metal concentrations (Nahmani et al. 2007). Very few studies have been published on determination of the body burden of mercury from soil metal content, hence direct comparison is difficult. However, values for other heavy metals are available e.g. $\mathrm{Cd}=0.47 \pm 0.12$ and $\mathrm{Pb}=0.27 \pm 0.15$ (Nahmani et al. 2007). Predictions of body burden from soil metal content are log-linear regressions of the form:

$$
\log \mathrm{M}_{\mathrm{ew}}=a \log \mathrm{M}_{\mathrm{s}}+b
$$

where $\mathrm{M}_{\mathrm{ew}}=$ concentration of metal in the earthworm $(\mu \mathrm{g} / \mathrm{g}) ; \mathrm{M}_{\mathrm{s}}=$ concentration of metal in the soil $(\mu \mathrm{g} / \mathrm{g}) ; a$ and $b$ are constants.

Body burdens where calculated by plotting $\mathrm{M}_{\mathrm{ew}}$ versus $\mathrm{M}_{\mathrm{s}}$ with $a=$ slope and $b=$ intercept (Nahmani et al. 2007). The slope of the regression equation is metal dependent (Corp and Morgan 1991; Heikens et al. 2001) (Fig. 11).

Following the literature precedent we have calculated values for $a$ and $b$ from the respective linear plot obtained for $\mathrm{Hg}^{2+}$. The values for $b$ were observed to be relatively constant but greater variation was observed in the value for $a$. Variation in $a$ could be due to the absence/presence of HA and the difference in temperature (Table 7).

The values of $a$ for body burden of $\mathrm{Hg}^{2+}$ at the lower temperature was comparable to values of $a$ determined for other metal species. As noted before, the higher temperature was not tolerated well by the earthworms and resulted in early expiration and hence this factor could influence the body burden data. 


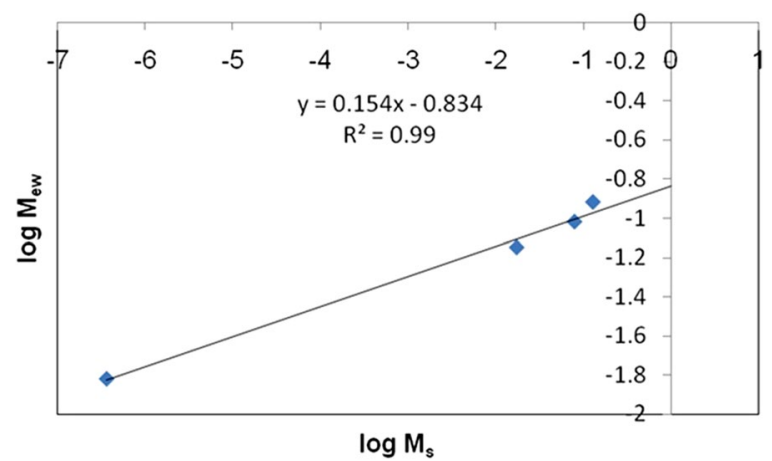

Fig. 11 Determination of body burden constants from soil Hg content

Table 7 Body burden constants for the complexation of $\mathrm{Hg}$ with HA in dry experiments with earthworms at $298.15 \mathrm{~K}$ and $303.15 \mathrm{~K}$

\begin{tabular}{|c|c|c|c|c|}
\hline & $298.15 \mathrm{~K}$ & & 303.15 & \\
\hline & Control (without HA) & Sample (with HA) & Control (without HA) & Sample (with HA) \\
\hline$a$ & $0.15 \pm 0.07$ & $0.10 \pm 0.04$ & $0.05 \pm 0.02$ & $0.38 \pm 0.11$ \\
\hline$b$ & 0.83 & 0.82 & 0.85 & 0.80 \\
\hline
\end{tabular}

\section{Discussion}

Earthworms are important bioindicators of soil contamination. Bioavailability of $\mathrm{Hg}$ depends on the speciation, which in turn determines the toxicity, transport, and residual time of the metal in the environment. Abiotic speciation is mainly due to mercury-ligand formation. Previous studies (Burton et al. 2006; Ernst et al. 2008) have found that earthworms could survive highly contaminated soil of up to $22 \mu \mathrm{g} / \mathrm{g} \mathrm{Hg}$ and concentrations of up to $6.5 \mu \mathrm{g} / \mathrm{g} \mathrm{Hg}$ have been found in earthworms. Colacevich et al. (2011) found that long term exposure of earthworms to Hg-contaminated soil of up to $1287 \mathrm{mg} / \mathrm{kg}$ dry wt did not cause earthworm mortality. The ability of earthworms to convert $\mathrm{Hg}^{2+}$ to $\mathrm{MeHg}$ was also indicated by the speciation results obtained by Santoyo et al. (2011). Veiga et al. (1999) and Kaschak et al. (2014) found that methylation could occur in the gut of earthworms, but upon analysis found only about $1 \% \mathrm{MeHg}$ in the total $\mathrm{Hg}$ in the tissues.

The detailed kinetic approach that was demonstrated in our work makes a noteworthy contribution to the understanding of the kinetics of mercury uptake by earthworms. Mercury distribution profiles as a function of time. Bioaccumulation factors (BAFs), first order rate constants and body burden constants for mercury uptake under selected conditions of temperature, $\mathrm{pH}$ as well as via the dermal and gut route were evaluated in one comprehensive approach. Body burden constants for mercury uptake by earthworms were determined in this work and are reported here for the first time, since no previous reports for reference values were found. This work therefore represents a major contribution to the available knowledge in the evaluation of mercury uptake by earthworms.

\section{Conclusion}

Trends in the uptake of $\mathrm{Hg}^{2+}$ by selected invertebrates, earthworms Eisenia andrei, were evaluated at different time interval, up to 5 days. $\mathrm{Hg}$ analysis of soil, water and earthworm samples was done using standard DMA method. Uptake of Hg by earthworms at 
$293.15 \mathrm{~K}$ was almost immediate, and concentration of up to $75 \%$ of the original spiked value was found at $\mathrm{pH} 5.5$ and $\mathrm{pH} 7.0$ after $48 \mathrm{~h}$. The control sample also showed the same swift uptake and high amount of $\mathrm{Hg}$ in the earthworms. The rate constant was determined to be 0.4 in the control sample. In the samples where HA was present in the biosystem, the rate constant was $0.8-1$ and $\mathrm{Hg}$ accumulation was favoured by low $\mathrm{pH}$ and low temperature. The body burden constants determined, were in good agreement with values reported for other divalent metal species.

In the samples containing only the soil and earthworms (no aqueous phase) at $298.15 \mathrm{~K}$ the $\mathrm{Hg}$ uptake was higher $(84 \%)$ in the sample containing the HA than in the control (34\%). The rate of uptake was the same with rate constant of 0.4 . The control sample (no HA added), thus showed a similar trend over time, but reduced concentration accumulation of HA. This data suggests that bioavailability of $\mathrm{Hg}$ is enhanced through complexation with HA, thereby increasing the uptake of $\mathrm{Hg}$ by earthworms. Total $\mathrm{Hg}$ unaccounted for was only $1 \%$ at $297.15 \mathrm{~K}$ in the presence of HA, but $45 \%$ in control at $48 \mathrm{~h}$.

We have clearly demonstrated that the uptake of $\mathrm{Hg}$ was influenced by $\mathrm{pH}$, temperature and HA as supported by calculated values of BAF $(0.1-0.8)$ and rate constants from (0.2 to 1). The body burden of $\mathrm{Hg}$ was found to be $\mathrm{a}=0.05-0.4$ and $b$ was found to be constant at 0.8 . The higher temperatures and $\mathrm{pH}$ were not favourable for uptake of $\mathrm{Hg}^{2+}$ in earthworms or indeed survival of the earthworms.

\section{Authors' contributions}

$\mathrm{SL}$ is the PhD candidate who was the lead researcher carrying out the experimental work and prepared the first draft of the manuscript. AC was the principal investigator on the project responsible for conceptualizing the study, developing the research strategies and providing primary funding for the project. PB was responsible for data analysis and interpretation and co-ordinating the preparation of the final manuscript. All authors read and approved the final manuscript.

\section{Author details}

${ }^{1}$ SensorLab, Chemistry Department, University of the Western Cape, PB X17, Bellville 7535, South Africa. ${ }^{2}$ Faculty of Science, University of the Witwatersrand, Private Bag 3, Johannesburg 2050, South Africa.

\section{Acknowledgements}

A special thanks to the Council for Scientific and Industrial Research (CSIR, Stellenbosch, South Africa), Natural Resources and the Environment unit, for DMA analysis.

\section{Competing interests}

The authors declare that they have no competing interests.

Received: 1 March 2016 Accepted: 5 May 2016

Published online: 20 May 2016

\section{References}

Álvarez FF, Rodríquez TR, Espinosa AJF, Dabán AG (2004) Physical speciation or arsenic, mercury, lead, cadmium and nickel in inhalable atmospheric particles. Anal Chim Acta 524:33-40

Arnold RE, Langdon CJ, Hodson ME, Black S (2003) Development of a methodology to investigate the importance of chemical speciation on the bioavailability of contaminants to Eisenia andrei. Pedobiologia 47:633-639

Burton DT, Turley SD, Fisher DJ, Green DJ, Shedd TR (2006) Bioaccumulation of total mercury and monomethylmercury in the earthworm Eisenia fetida. Water Air Soil Pollut 170:37-54

Calisi A, Zaccarelli N, Lionetto MG, Schettino T (2013) Integrated biomarker analysis in the earthworm Lumbricus terrestris: application to the monitoring of soil heavy metal pollution. Chemosphere 90:2637-2644

Colacevich A, Sierra MJ, Borghini F, Millán R, Sanchez-Hernandez JC (2011) Oxidative stress in earthworms short- and long-term exposed to highly Hg-contaminated soils. J Hazard Mater 194:135-143

Corp N, Morgan AJ (1991) Accumulation of heavy metals from polluted soils by earthworm, Lumbricus rubellus: can laboratory exposure of 'control'worms reduce biomonitoring problems? Environ Pollut 74:39-52

Dai J, Becquer T, Rouiller JH, Reversat G, Berhard-Reversat F, Nahmani J, Lavelle P (2004) Heavy metal accumulation by two earthworm species and its relationship to total and DTPA-extractable metals in soils. Soil Biol Biochem 36:91-98

Ernst G, Zimmermann S, Christie P, Frey B (2008) Mercury, cadmium and lead concentrations in different ecophysiological groups of earthworms in forest soils. Environ Pollut 156:1304-1313 
Gårdfeldt K, Munthe J, Strőmberg D, Lindqvist O (2003) A kinetic study on the abiotic methylation of divalent mercury in aqueous phase. Sci Total Environ 304:127-136

Gismera MJ, Procopio JR, Sevilla MT (2007) Characterization of mercury-humic acids interaction by potentiometric titration with a modified carbon paste mercury sensor. Electroanalysis 19(10):1055-1061

Gudbrandsen M, Sverdrup LE, Aamodt S, Stenersen J (2007) Short-term pre-exposure increases earthworm tolerance to mercury. Eur J Soil Biol 43:S261-S267

Heikens A, Peijnenburg WJGM, Hendriks AJ (2001) Bioaccumulation of heavy metals in terrestrial invertebrates. Environ Pollut 113:385-393

Hobbelen PHF, Koolhass JE, Van Gestel CM (2006) Bioaccumulation of heavy metals in the earthworms Lumbricus rubellus and Aporrectodea caliginosa in relation to total and available metal concentrations in field soils. Environ Pollut 144:639-646

Inza B, Ribeyre F, Maury-Brachet R, Boudou A (1997) Tissue distribution of inorganic mercury, methylmercury and cadmium in the Asiatic clam (Corbicula fluminea) in relation to the contaminant levels of the water column and sediment. Chemosphere 35(12):2817-2836

Ipolyi I, Massanisso P, Sposato S, Fodor P, Morabito P (2004) Concentration levels of total and methylmercury in mussel samples collected along the coasts of Sardinia Island (Italy). Anal Chim Acta 505:145-151

Kading TJ, Mason RP, Leaner JJ (2009) Mercury contamination history of an estuarine floodplain reconstructed from a ${ }^{210} \mathrm{~Pb}$-dated sediment core (Berg River, South Africa). Mar Pollut Bull 59:116-122

Kamitani T, Kaneko N (2007) Species-specific heavy metal accumulation patterns of earthworms on a floodplain in Japan. Ecotoxicol Environ Saf 66:82-91

Kaschak E, Knopf B, Petersen JH, Bings NH, König H (2014) Biotic methylation of mercury by intestinal and sulfate-reducing bacteria and their role in mercury accumulation in the tissue of the soil-living Eisenia foetida. Soil Biol Biochem 69:202-211

Lawrence AL, Mason RP (2001) Factors controlling the bioaccumulation of mercury and methylmercury by the estuarine amphipod Lectocheirus plumulosus. Environ Pollut 111:217-231

Li L, Xu Z, Wu J, Tian G (2010) Bioaccumulation of heavy metals in the earthworm Eisenia fetida in relation to bioavailable metal concentrations in pig manure. Bioresour Technol 101(10):3430-3436

Nahmani J, Hodson ME, Black S (2007) A review of studies performed to assess metal uptake by earthworms. Environ Pollut 145:402-424

Nannoni F, Protano G, Riccobono F (2011) Uptake and bioaccumulation of heavy elements by two earthworm species from a smelter contaminated area in northern Kosovo. Soil Biol Biochem 43:2359-2367

Rodríquez Álvarez C, Jimènez Moreno M, Guzmán Bernado FJ, Rodríquez Martín-Doimeadios RC, Berzas Nevado JJ (2014) Mercury methylation, uptake and bioaccumulation by earthworm Lumbricus terrestris (Oligochaeta). Appl Soil Ecol 84:45-53

Santoyo MM, Flores CR, Torres AL, Wrobel K, Wrobel K (2011) Global DNA methylation in earthworms: a candidate biomarker of epigenetic risks related to the presence of metals/metalloids in terrestrial environments. Environ Pollut 159:2387-2392

Sizmur T, Hodson ME (2009) Do earthworms impact metal mobility and availability in soil? A review. Environ Pollut 157:1981-1989

Steenbergen NTTM, laccino F, De Winkel M, Reijnders L, Peijnenburg WJGM (2005) Development of a biotic ligand model and a regression model predicting acute copper toxicity to the earthworm Aporrectodea caliginosa. Environ Sci Technol 39:5694-5702

Veiga M, Hinton J, Lilly C (1999) Mercury in the Amazon: a comprehensive review with special emphasis on bioaccumulation and bioindicators. In: Proceedings of National Institute for Minamata Disease (NIMD) Forum 99, Minamata, Japan

Windmöller CC, Durão Júnior WA, de Oliveira A, do Valle CM (2015) The redox processes in Hg-contaminated soils from Descoberto (minas Gerais, Brazil): implications for the mercury cycle. Ecotoxicol Environ Saf 112:201-211

\section{Submit your manuscript to a SpringerOpen ${ }^{\circ}$ journal and benefit from:}

- Convenient online submission

- Rigorous peer review

- Immediate publication on acceptance

- Open access: articles freely available online

- High visibility within the field

- Retaining the copyright to your article

Submit your next manuscript at $\boldsymbol{\nabla}$ springeropen.com 